\title{
The Effect Of Enriched Learning Environment To Turkish Geometry For International Students
}

\author{
Kübra KARAKAYA-ÖZYER \\ Eskisehir Osmangazi University, kozyer@ogu.edu.tr
}

\begin{abstract}
Because of the increasing number of internaitonal students in Turkey in the last 5 years, Turkish Language preparation courses has founded in the different areas. It is crucial to evaluate the effectiveness of these courses applications. In this study, semi-experimental design was used to compare the Turkish geometry knowledge of internaitonal students from two different language level. Sample was a total of 44 international students from a Turkish Language Preparation Course at a public university. ANCOVA analysis demonsrated that there is no significant difference between Experiment1 and Control1 groups in terms of their Turkish geometry knowledge. In other words, there is no enriched learning environment effect on Turkish geometry knowledge. Moreover, independent t-test analysis between Experiment 2 and Control 2 showed that there is a statistically significant difference in terms of their Turkish geometry knowledge. However, the mean of the geometry tests indicated that control 2 group has more Turkish geometry knowledge than Experiment2 group. The experiment concluded that there are other important variables that should considered to analyze international students Turkish geometry knowledge in enriched learning enviroment.
\end{abstract}

Key words: Geogebra, Turkish as a second language, geometry 


\section{Zenginleştirilmiş Öğrenme Ortamının Uluslararası Öğrencilerin Türkçe Geometri Bilgisine Etkisi}

Son 5 yılda Türkiye'nin uluslararası öğrencilerin odak noktası olmasıyla çeşitli illerde Türkçeyi yabancı dil olarak öğreten merkezler kurulmuştur. Bu merkezlerde yapılan uygulamaların ne kadar etkili olduğunun ortaya çıartılması önem kazanmıştır. $\mathrm{Bu}$ çalışmada yarı-deneysel desen kullanılmış olup iki farklı dil seviyesindeki öğrencilerin Türkçe geometri bilgileri karşıllaştırılmıştır. Çalışmanın örneklemi olarak bir devlet üniversitesindeki Türkçe Öğretim Merkezinde öğrenim gören 4 farklı sinıftan 44 uluslararası öğrenciden oluşmaktadır. Sonuç olarak, Deney1 ve Kontroll grupları arasında Türkçe geometri bilgi erişi düzeylerinin farklılığı için yapılan ANCOVA testi sonucunda gruplar arasında anlamlı bir fark olmadığı ortaya çıkmıştır. Diğer bir ifadeyle Deney1 grubuna yapılan zenginleştirilmiş ortamla öğretim uygulamaları etkili olmamıştır. Ek olarak, Deney2 ve Kontrol2 grupları için yapılan bağımsız örneklem ttesti sonucu iki grup arasında anlamlı bir farklılık vardır $(\mathrm{p}<.05)$. Ancak grupların Türkçe geometri bilgi erişi düzeylerinin ortalamalarına bakıldığında Kontrol2 grubunun genel bilgi açısından daha yüksek erişi düzeyine sahip olduğu sonucunu çıkartmaktadır. $\mathrm{Bu}$ deneysel çalışma gösteriyorki uluslararası öğrencilerin zenginleştirilmiş öğrenme ortamındaki Türkçe geometri bilgilerini inceleyebilmek için farklı değişkenleri işin içine katılması gerekmektedir.

Anahtar Kelimeler: Geogebra, yabancılara Türkçe, geometri.

\section{GíRiş}

"Bir dil bir insan, iki dil iki insan."

Diller; kültürleri ve insanları birbirine bağlayan köprülerdir. O köprüleri bilmek demek toplumların davranış şekillerini, geçmişten bugüne taşıdıkları miraslarını ve yaşam felsefelerini öğrenmek demektir (Edmonson ve House, 1993, Aktaran: Aktaş, 2005).

Sürekli değişsen iletişim dünyasında, yabancı bir dil bilmek dünyadaki diğer insanlarla etkileşim halinde olmanın en önemli şartı oldu. Son yıllarda Türkiye'nin ekonomi, siyaset, bilim ve askeri alanda kendini ispat etmesi ve sesini tüm dünyaya duyurmasıyla, Türkçe birçok kişi tarafından ilgi odağı haline geldi.

Türkiye'nin uluslararası bilim alanlarında tanınmaya başlamasıyla yabancı uyruklu öğrencilerin eğitim ve öğretim için Türkiye'ye talepleri artmıştır. 2015 yılında 


\section{Karakaya-Özyer}

Kalkınma ajansının yayınladığı rapora göre; 2013-2014 eğitim yılında toplam 48.183 uluslararası öğrenci çoğunluğu devlet üniversiteleri olmak üzere Türk üniversitelerine kayıt yaptırmıştır. 2015 yılında yaklaşık 100.000 yabancı öğrenci hedeflendiği göz önünde bulundurulursa, Türkçe öğretiminin önemi bir kat daha artmaktadır.

Günümüz insanın elinde bulunan en önemli iki araç şüphe yok ki internet ve bilgisayardır. $\mathrm{Bu}$ teknolojiler günlük hayattaki yerlerinin yanı sıra eğitim ve öğretim alanındaki konumlarını gün geçtikçe genişletmektedirler. Dil öğretimi de teknolojik gelişmelere her daim ihtiyaç duyan ve bu gelişmelerden olumlu yönde etkilenen bir alandır (Yücer, 2011). Yeni bir dil öğretirken bu yeni teknolojileri kullanmak hem çağın bir gereğini yerine getirilmiş olur hem de öğrenenlerin daha nitelikli yetişmelerine yardımcı olur (İçel, 2011). İnsan hayatına her geçen gün bir kat daha fazla giren bilgisayarlar ise dil öğretim programlarının olmazsa olmazı haline gelmiştir. Özellikle Türkçe öğrenenlerin çoğunluğunun genç olması ve küreselleşen dünyanın en yaygın teknolojisinin bilgisayar olmasıyla, Türkçe öğretiminde bilgisayar tabanlı etkinlikler yapılması giderek zorunlu hale gelmektedir.

Dinamik geometri yazılımları da bu teknolojik gelişmelerin en önde gelenlerinden biri olmuştur. Bu yazılımlar sayesinde öğrencilerin matematiğe ve geometriye yatkınlıkları artacak ve dolaylı olarak problem çözme becerilerinde gelişmeler olacaktır (Baki, Güven ve Karataş, 2004; İçel, 2011). Buna ek olarak, dinamik geometri yazılımları aracılığıyla yapılan geometri öğretimi öğrencilerin o konuyu daha sonraları hatırlamalarını kolaylaştıracak ve geometri dersinde öğrendiği kavramları ve ilişkileri diğer alanlara da daha kolay aktaracaklardır (Baki, Güven ve Karataş, 2004; İçel, 2011). Yabancılara Türkçe öğretim programlarında bilgisayarlar genellikle sunum hazırlama, video izletme ve müzik dinletme amaçlarıyla kullanılmaktadır. Ancak, dinamik geometri yazılımları gibi özel bir amaca hizmet eden bilgisayar programları Türkçe'nin yabancı dil olarak öğretiminde göz ardı edilmektedir. 


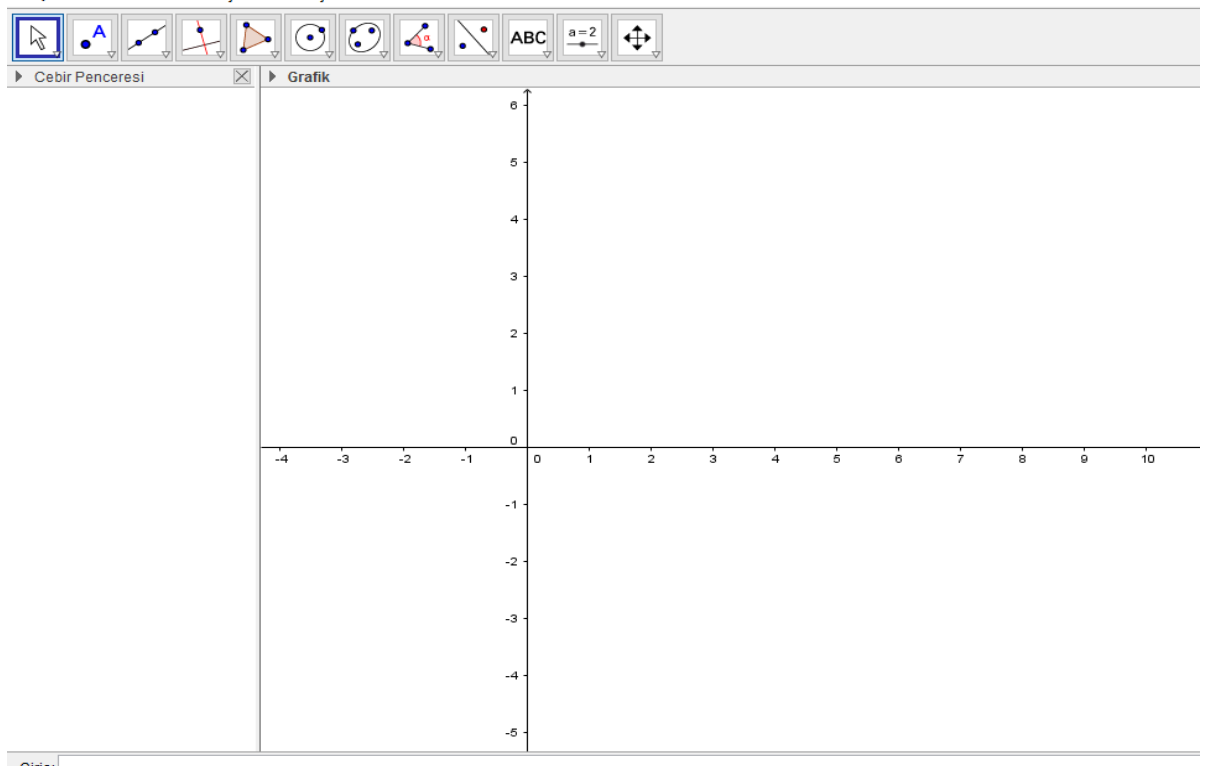

Şekil 1. GeoGebra dinamik geometri yazılımı

GeoGebra geometri yazılımına ek olarak, deney gruplarına ders içeriklerini açıklayan powerpoint sunuları gösterilmiştir. Bu sunumlarda kısa kavramsal tanımların ve formüllerin yanında örnek sorular verilmiştir. Yapılan çalışmalar gösteriyor ki powerpoint ile yapılan öğretimin geleneksel yöntemlerle yapılan öğretime nazaran akademik başarıya etkisi daha fazladır (Akdağ ve Tok, 2008; Bartsch ve Cobern, 2003; Özdemir ve Tabuk, 2004).

Yapılan araştırmalara göre geometri dersinde öğrencilere yapılan etkinlikler yetersiz kalmakta, verilen etkinliklerin de öğrenci odaklı olmaktan çok öğretmen odaklı olduğu ortaya çıkmaktadır (Topbaş, 2008). Öğretim sürecinde sınıfta yapılan etkinliklerinle öğrenciler kavramları keşfetmelerine ve yaparak yaşayarak öğrenmelerine yeterince imkân verilmesi öğrencilerin Türkçe öğrenmelerine olumlu yönde etkilemektedir (Demirel, Seferoğlu ve Yağc1, 2002).Öğrencilerin yaparak ve yaşayarak öğrenmelerini desteklemek amaciyla oyun hamuru ve kürdanlardan oluşan bir etkinlik sunulmuştur. $\mathrm{Bu}$ etkinlikle öğrencilerin geometrik şekilleri öğrenmeye heyecanları artırılması 


\section{Karakaya-Özyer}

hedeflenmiştir. Ek olarak, bu etkinlikle derste bilgisayar üzerinden öğretilen soyut kavramların somutlaştırılması planlanmıştır. Bu etkinlikte öğrencilere belirli bir miktar oyun hamuru ve kürdan verilerek onlardan derste öğrendikleri kavramları somutlaştırmaları istenmiştir. Şekil 2'de öğrencilerin sınıfta yaptıkları etkinlikten bir örnek verilmiştir.

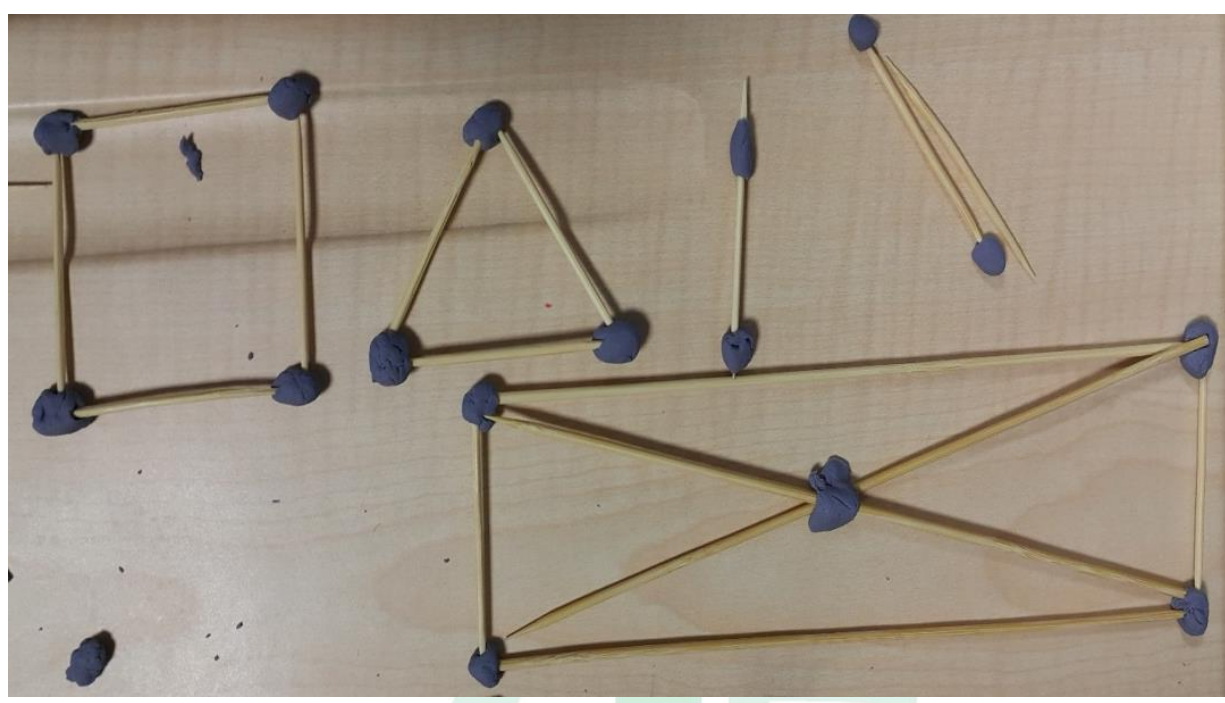

Şekil 2. Oyun hamuru ile geometri öğretimi etkinliği

Kavram öğretiminde etkililiği sağlamada yardımcı olan materyallerden biri de çalışma yapraklarıdır. Kullanıcının yani öğrencinin ihtiyacına göre çeşitli şekillerde hazırlanabilen çalışma yaprakları (Ceyhan ve Türnüklü, 2002) iyi hazırlanmış olması durumda öğrencide konuya odaklanmaya yardımcı olmaktadır. Bunun yanı sıra, çalışma yapraklarıyla birden fazla durumda aynı kavramları inceleme firsatı bulan öğrenciler, kavram yanılgılarından kendi çabalarıyla kurtulabilmektedirler. Böylece daha etkili, anlamlı ve kavram yanılgılarından uzak bir şekilde öğrenme ortamı oluşturulmuş olmaktadır (Hand ve Treagust, 1991; Yiğit, Akdeniz ve Kurt, 2001). Mevcut çalışmada da deney grubundaki öğrencilere her uygulama sonrasında çalışma kâğıtları dağıtılmış, bu sayede derste öğrendikleri bilgilerin tekrarı ve kalıcılığı sağlanmaya çalışılmıştır.

Yabancılara Türkçe öğretiminin kendine has zorluklarının yanında görselliğe en çok ihtiyaç duyulan matematiksel ve geometrik kavramların yabancı öğrencilere 


\section{Zenginleştirilmiş Öğrenme Ortamının Uluslararası Öğrencilerin Türkçe Geometri Bilgilerine Etkisi}

anlatımında farklı zorluklar ortaya çıkmış ve yeni yöntemlere ihtiyaç duyulmuştur. Özellikle Türkiye'de akademik bir hayat beklentisi içinde olan öğrencilerin temel geometrik şekillerin isimlerini ve ne işe yaradıklarını öğrenmeleri zorunlu hale gelmiştir. Yabancı Öğrenci Sınavı (YÖS)'nın matematik kısmının olması yabancı öğrencilerde kısmi de olsa Türkçe matematik kavramlarını öğrenme isteği oluşturmuştur. Nokta, düzlem, kesit, doğru, doğru parçası, ş̧ın, doğru çeşitleri, açı ve açı çeşitleri, üçgen ve dörtgenler, çember, köşegen, yükseklik, çevre ve alan gibi temel geometrik kavramlar başlangıç seviyesinde öğretilmesi amaçlanan geometri öğretimi hedefleri olmuştur. Bu kavramların görsel olarak ifade edilebilmesi, geometrik şekillerin Türkçe cebirsel karşıtlarının aynı anda gösterilebilmesi, tek bir platformda birden çok geometrik kavramı tanıtabilmesi, ilköğretimden üniversiteye kadar her seviyeye hitap etmesi ve geometrik şekilleri 3 boyutlu ortama aktarabilmesi gibi sebeplerden dolayı GeoGebra yazılımı yabancı öğrencilere Türkçe geometrik kavramları tanıtmada yardımcı olacaktır. İlköğretim, lise ve üniversite öğrencileri için GeoGebra ile geometri öğretiminin öğrencilerin akademik başarılarına katkısı birçok araştırmacı tarafından incelenmiş̧ (örneğin; Doğan ve İçel, 2011; Erol, Özdemir, Özen, Akadal ve Ayvaz-Reis, 2012), ancak Türkçe'yi yabancı dil olarak öğrenen kişiler üzerindeki etkisi henüz araştırma konusu haline gelmemiştir. Bu araştırmada, Türkiye'de Türkçe öğrenen yabancı uyruklu öğrencilerini temel geometri kavramlarını zenginleştirilmiş öğrenme ortamı ile öğretmenin onların matematik başarılarına etkisi incelenmek istenmiştir.

Problem: Zenginleştirilmiş öğrenme ortamı yararlanılarak yapılan Türkçe geometri öğretiminin uluslararası öğrencilerin Türkçe geometri kavramsal ve işlemsel bilgilerine ilişkin erişi düzeylerinin geleneksel öğrenme ortamına göre anlamlı bir farkı var mıdır? Diğer bir deyişle "Deney ve kontrol gruplarının genel Türkçe geometri bilgiye ilişkin erişi düzeylerinin arasında anlamlı bir fark var mıdır?" sorusuna cevap aranmıştır.

\section{YÖNTEM}

$\mathrm{Bu}$ çalı̧̧ma bir yarı-deneysel çalışma olup, bu araştırma ile zenginleştirilmiş öğrenme ortamı (GeoGebra programının, oyun hamuru etkinliklerinin ve çalışma yapraklarının uygulandığı) içinde bulunan öğrencilerin mevcut geometri bilgileri ile kazanılan geometri bilgileri karşılaştırılmak istenmektedir. Bu amaçla yarı-deneysel, çok denekli ve eşitlenmiş kontrol gruplu ön-test-son-test bir deney desenlenmiştir. Araştırmada kullanılacak 4 gruptan ikisi üst düzey A2 ve ikisi orta düzey A2 grubu biçimindedir. Üst düzey sınıflardan bir tanesi rassal olarak seçilerek deney grubu yapılmıştır. Orta düzey 


\section{Karakaya-Özyer}

iki sınıftan bir tanesi de yine rassal olarak seçilmiş ve deney grubu yapılmıştır. Bu çalışmada kullanılacak olan desen Tablo 1' de gösterilmiştir.

Tablo 1

Araştırma deseni

\begin{tabular}{cccc}
\hline Gruplar & Ön-test & Uygulama & Son-test \\
\hline $\mathrm{G}_{1}$ & $\mathrm{O}_{1,1}$ & $\mathrm{X}$ & $\mathrm{O}_{2,1}$ \\
$\mathrm{G}_{2}$ & $\mathrm{O}_{2,1}$ & - & $\mathrm{O}_{2,2}$ \\
$\mathrm{G}_{3}$ & $\mathrm{O}_{3,1}$ & - & $\mathrm{O}_{3,2}$ \\
$\mathrm{G}_{4}$ & $\mathrm{O}_{4,1}$ & $\mathrm{X}$ & $\mathrm{O}_{4,2}$ \\
\hline
\end{tabular}

Öncelikle, araştırmacı ve dersin eğitmeni ile beraber geometri eğitiminin hedef ve davranışları belirlenmiş, bu hedefleri ve yeterli soru sayılarını gösteren bir belirtke tablosu oluşturulmuştur. Böylece hazırlanan ön-testin kapsam geçerliliği sağlanmaya çalışılmıştır. Belirtke tablosuna göre hazırlanan ön-test sorularını yabancılara Türkçe konusundaki alan uzmanına sunulmuş, gerekli düzenlemeler yapılarak bir devlet üniversitesine bağlı TÖMER'deki 3 öğrenci ile pilot bir çalışma yapılmıştır. Farklı seviyelerden alınan bu öğrencilere sorular farklı zamanlarda sorular verilerek öğrencilerin soruları çözmeleri istenmiş, onların sözel ifadeleri ve mimikleri gözlemlenerek ön-testteki eksiklikler saptanmaya çalışılmıştır. Üç öğrenci ile yapılan nitel bir araştırma sonucunda yeniden düzenlenen ön-test A2 seviyesindeki 4 gruba uygulanmıştır. Ön-test uygulanmadan önce dersin eğitmeni ve araştırmacı tarafından ayrıntılı bilgi verilmiştir. Türkçe anlamayanlar için araştırmanın amacı, kazanımları, beklentileri ve süreci İngilizce ve Arapça olarak hazırlanmış bir bilgilendirme formu dağıtılmıştır. Araştırmaya katılmak istemeyen öğrenciler belirlenerek örneklem grubundan çıkartılmıştır. Çalışmaya katkıda bulunmaya istekli kişiler belirlendikten sonra geometri kavramsal ve işlemsel bilgi testleri ön-testler olarak uygulanmıştır.

Üç haftalık eğitimden sonra her dört gruba da bir son test uygulaması yapılmıştır. Soruların hepsi yine basit geometrik şekiller konusunun kazanımlarını içermekte olup, uygulanan son test kavramsal ve işlemsel bilgiyi ölçmeye yönelik iki bölümden oluşmuştur. Son test zenginleştirilmiş öğrenme ortamının öğrencinin geometri başarısına etkisini görmek amacıyla yapılmıştır.

\section{Araştırma Örneklemi}


Deney uygulaması, bir devlet üniversitesine bağlı Türkçe öğretim merkezine (TÖMER) 2014-2015 öğretim yılında kayıtlı olan A2 seviyesindeki öğrenciler üzerinde gerçekleşmiştir. A2 seviyesindeki öğrenciler kur sonu seviye tespit sınaviyla düşük, orta ve yüksek düzeyde Türkçe'ye sahip olanlar şeklinde 6 gruba ayrılmıştır. Ancak araştırmaya grupların homojenliği göz önüne alınarak yalnızca yüksek ve orta düzey A2 öğrencileri dâhil edilmiştir.

\section{Veri Toplama Araçları}

Yabanc1 öğrencilerin ön ve son geometri bilgileri, 2 alt boyuta sahip bir ölçek yardımıyla belirlenmiştir. Bu alt boyutlar geometri kavramsal bilgi ve geometri işlemsel bilgidir. Veri toplama aracı olarak her dört gruba araştırmacı ve matematik uzmanı tarafından geliştirilen ve ders kazanımlarına uygun kavramsal ve işlemsel öğrenmeleri ölçen bir snav uygulanmıştır. $\mathrm{Bu}$ ölçme aracında geometri sorularından önce öğrencilerin kişisel özelliklerini belirlemek amacıyla öğrenci bilgi formu verilmiştir. Böylece öğrencilerin yaşları, cinsiyetleri, hangi ülkeden geldikleri, hangi bölümde öğrenim görecekleri ve matematiğe karşı tutumlarını tespit etmek istenmiştir. Ölçekteki sorular seçilirken öncelikle Türkçe öğretim merkezinde ders vermekte olan matematik öğretmeninden fikir alınmış, uygulamanın kapsama alanı belirlenmiştir. Sonrasında Milli Eğitim Bakanlığının ilk ve ortaokullar için hazırladığı müfredat programı incelenerek basit geometrik kavramların hedef kazanımları tespit edilmiştir. Tespit edilen kazanımları ölçmek için gerekli olan sorular güvenilir kaynaklardan toplanıp bir soru havuzu haline getirilmiştir. Bu soru havuzundaki sorular kavramsal ve işlemsel bilgiyi ölçmelerine göre ayrılmış, dilsel ve kapsam geçerliliği sağlandıktan sonra Türkçe eğitim merkezindeki birkaç öğrenciden görüş alınmıştır. Yabancı öğrencilerden alınan geri-dönütler doğrultusunda düzenlenen ve son hali verilen ön-test ve son-test ölçme araçlarının değerlendirme kısmı araştırmacı tarafından yapılmıştır. Her bir testteki sorular toplam 100 puana sahip olmakla birlikte içerdiği soruların puan ağırlıkları değişmektedir. Ek olarak, öğrencilerin sorulara nasıl cevap verdiklerini ve cevap veremedikleri soruların nedenini tespit etmek için çözüm kısmına ek bir bölme yaparak nitel veriler toplamak amaçlanmıştır. Deneysel çalışma sonunda ise her gruptan 3'er öğrenci seçilerek yapılan uygulamaya karşı tutumları, fikirleri ve eleştirileri tespit edilmiştir.

\section{BULGULAR}

Türkçe Geometri Genel Bilgi Düzeyine İlişkin Sonuçlar 


\section{Karakaya-Özyer}

Türkçe geometri kavramsal ve işlemsel bilgi düzeylerini incelendikten sonra yabancı ögrencilerin genel manada gelişimlerini araştırılmıştır.

Tablo 2’te Deney1 ve Kontrol1 grubundaki öğrencilerin Türkçe geometri bilgi ölçeğinin tamamına ait verilerinin betimleyici istatistikleri bulunmaktadır. Türkçe geometri bilgi testi 100 puan üzerinden puanlanmıştır. Bu tabloya göre Deneyl grubu öğrencilerinin Türkçe geometri testine ait ön-test puanlarının aritmetik ortalaması 51.23, standart sapması 22.59; Kontrol1 grubu öğrencilerinin Türkçe geometri ön-test puanlarının aritmetik ortalaması 24.33, standart sapması 21.62 şeklinde ortaya çıkmıştır. Ek olarak, Deney1 grubu öğrencilerinin yine 100 puan üzerinden değerlendirilen Türkçe geometri testine ait son-test puanlarının aritmetik ortalamas 186.88 , standart sapması 16.65 olarak bulunurken; Kontrol1 grubu öğrencilerinin son-test puanlarının aritmetik ortalamas1 67.13, standart sapması 22.56 olarak hesaplanmıştır.

Tablo 2

Türkçe Seviyeleri Illeri Olan Deney ve Kontrol Grubundaki Öğrencilerin Türkçe Geometri Bilgilerine Ait Ön-test ve Son-test Puanlarına İlişkin Değerler

\begin{tabular}{lllll}
\hline & Grup & $\mathbf{n}$ & $\overline{\boldsymbol{x}}$ & ss \\
\hline Ön-test & Deney1 & 17 & 51.23 & 22.59 \\
& Kontrol1 & 15 & 24.33 & 21.62 \\
Son-test & Deney1 & 17 & 86.88 & 16.65 \\
& Kontrol1 & 15 & 67.13 & 22.56 \\
\hline
\end{tabular}

Tablo 3'te de Deney2 ve Kontrol2 grubundaki yabanc1 uyruklu öğrencilerin Türkçe geometri testi sonuçlarına dair bazı istatistiki bilgiler verilmiştir. Bu tabloya göre, Deney2 grubunun öğrencilerinin Türkçe geometri ön-test puanlarının ortalaması ise 13.06 ve standart sapması 14.94 iken Kontrol2 grubundaki öğrencilerin Türkçe geometri bilgi ön-test sonuçlarının ortalaması 17.58 ve standart sapması 13.86 olarak hesaplanmıştır. Diğer taraftan, Deney2 grubunun Türkçe geometri son-test sonuçları ortalamaları 54.50 ve standart sapmaları 19.74 ve Kontrol2 grubundaki öğrencilerin Türkçe geometri bilgi son-test puanlarının ortalamaları 81.41 ve standart sapmaları 10.05 biçimindedir.

Tablo 3

Türkçe Seviyeleri Orta Olan Deney ve Kontrol Grubundaki Öğrencilerin Türkçe Geometri Bilgilerine Ait Ön-test ve Son-test Puanlarına İlişkin Değerler 


\begin{tabular}{lcccc}
\hline & Grup & n & $\overline{\boldsymbol{x}}$ & ss \\
\hline Ön-test & Deney2 & 16 & 13.06 & 14.94 \\
& Kontrol2 & 12 & 17.58 & 13.86 \\
Son-test & Deney2 & 16 & 54.50 & 19.74 \\
& Kontrol2 & 12 & 81.41 & 10.05 \\
\hline
\end{tabular}

Grup içi ve gruplar arası kıyaslamalara geçmeden önce hangi tür istatistik yöntemini belirlemek amacıyla genel bilgi düzeyine ait verilerin normallik testleri yapılmıştır.

Tablo 4'te verilen sonuçlara göre ön-test ve son-testlerin karş̧laştırıldığı grup içi farkl1lık testlerinde parametrik olmayan testler tercih edilirken, gruplar arası farklılık testlerinde parametrik testler kullanılabilir.

Tablo 4

Genel Bilgi Düzeylerinin Normallik Testi Sonuçları

\begin{tabular}{cccc|ccc}
\hline & \multicolumn{2}{c}{ Ön-test } & \multicolumn{2}{c}{ Son-test } & \multicolumn{2}{c}{ Fark } \\
& \multicolumn{2}{c}{ Shapiro-Wilks } & \multicolumn{2}{c}{ Shapiro-Wilks } & \multicolumn{2}{c}{ Shapiro-Wilks } \\
\hline & İstatistik & $p$-değeri & İstatistik & $p$-değeri & İstatistik & $p$-değeri \\
\hline Deney1 & .961 & .659 & .734 & .000 & .954 & .514 \\
Kontrol1 & .887 & .061 & .941 & .398 & .964 & .765 \\
Deney2 & .839 & .009 & .955 & .575 & .970 & .834 \\
Kontrol2 & .914 & .237 & .957 & .735 & .934 & .422 \\
\hline
\end{tabular}

Grup içi farklılık analizi sonuçları. Deneysel araştırmaya katılan gruplar arasında herhangi bir ayırım yapmadan Türkçe geometri gelişimlerini analiz etmek için ön-test ve son-test puanları arasındaki farkın anlamlı olup olmadığına Wilcoxon İşaretli Sıralar testi ile bakılmıştır. Bu analiz sonuçları aşağıdaki Tablo 5'da verilmiştir.

Tablo 5 


\section{Karakaya-Özyer}

Tüm Gruplarının Türkçe Geometri Bilgi Düzeylerine Ait Ön-test-Son-test Wilcoxon Işaretli Siralar Test Sonuçları

\begin{tabular}{|c|c|c|c|c|c|c|}
\hline Grup & & $\mathbf{n}$ & $\begin{array}{c}\text { Sira } \\
\text { Ortalaması }\end{array}$ & $\begin{array}{c}\text { Sira } \\
\text { Toplamı }\end{array}$ & $\mathbf{Z}$ & $p$ \\
\hline \multirow[t]{3}{*}{ Deney1 } & Pozitif Sira & 17 & 9.00 & 153.00 & -3.622 & .000 \\
\hline & Negatif Sira & 0 & .00 & .00 & & \\
\hline & Eşit & 0 & - & - & & \\
\hline \multirow[t]{3}{*}{ Kontrol1 } & Pozitif sıra & 15 & 8.00 & 120.00 & -3.408 & .001 \\
\hline & Negatif Sira & 0 & .00 & .00 & & \\
\hline & Eşit & 0 & - & - & & \\
\hline \multirow[t]{3}{*}{ Deney2 } & Pozitif Sira & 16 & 8.50 & 136.00 & -3.517 & .000 \\
\hline & Negatif Sira & 0 & .00 & .00 & & \\
\hline & Eşit & 10 & - & - & & \\
\hline \multirow[t]{3}{*}{ Kontrol2 } & Pozitif Sira & 12 & 6.50 & 78.00 & -3.059 & .002 \\
\hline & Negatif Sira & 0 & .00 & .00 & & \\
\hline & Eşit & 0 & - & - & & \\
\hline
\end{tabular}

Tablo 5'te verilen bulgulara göre, deneye katılan tüm grupların Türkçe geometri bilgi testinden aldıkları deney öncesi ve sonrası puanları arasında anlamlı bir fark olduğu görülmektedir $(\mathrm{p}<.05)$. Tablodaki sıra toplamları göz önüne alındığında, gözlenen bu farkın pozitif sıralar, son test puan lehine olduğu görülmektedir. Bu bağlamda, verilen geometri dersinin her grup için öğrencilerin Türkçe geometri bilgi düzeyleri bakımından verimli geçtiği yorumu yapılabilir.

Gruplar Arası Farklılık Analizi Sonuçları. Deney grupları arasındaki Türkçe geometri bilgi erişi düzeylerinin farklılığını analiz edebilmek için deneye katılan gruplarının ön-test sonuçlarının benzerliği test edilir. Diğer bilgi düzeylerinde olduğu gibi eğer gruplar ön bilgileri bakımından farklı çıkarsa ön-testin etkisi arındırılarak ANCOVA tekniği kullanılır. Aksi takdirde bağımsız örneklem t-testi ile fark araştırılır (Büyüköztürk, 2015).

Tablo 6 

Türkçe Geometri Bilgilerine Etkisi

Deneyl ve Kontroll Grubu Öğrencilerinin Türkçe Geometri Bilgi Ön-test Puanlarının Mann Whitney-U Testi Sonuçları

\begin{tabular}{cccccc}
\hline Grup & n & Fark & Sira Toplamı & Z & $p$ \\
\hline Deney1 & 17 & 21.38 & 363.50 & -3.136 & .002 \\
Kontrol1 & 15 & 10.97 & 164.50 & & \\
\hline
\end{tabular}

$* p>0.05$

Mann-Whitney $U$ testi sonuçlarına göre $p$-değeri 0.05 'ten küçük olduğundan eğitim öncesi Deney1 ile Kontroll grupları arasındaki Türkçe geometri bilgi düzeyi ön-test sonuçları arasında anlamlı bir fark vardır. Bu demektir ki Deneyl ile Kontrol1 grupları Türkçe geometri bilgi düzeyinde eşlenmemiş gruplardır. $\mathrm{Bu}$ sebepten, iki grup arasındaki farklılığa bakılmak istendiğinde ANCOVA yöntemi uygundur.

ANCOVA testi yapılmadan önce gruplar bağımsız değişkeni ile genel bilgi düzeyinin ön-test sonuçları arasında bir ilişki olup olmadığı test edilmiştir. Bu sonuçlara göre bağımsız değişken ile kovaryant değişken arasında bir ilişki bulmamıştır $(p=.374>$ $.05)$.

ANCOVA analiz sonuçları Tablo 7'de ifade edilmiştir. ANCOVA testi kapsamında yapılan Levene'nin hata varyansları eşitliği testi sonuçlarına göre hata paylarının varyansları eşittir. Bu eşitlik sağlandıktan sonra ANCOVA sonuçları yorumlanabilir.

Tablo 7

Deneyl ve Kontroll Grupları Arasında Türkçe Geometri Bilgi Düzeyinde Farklılık ANCOVA Testi Sonuçlarl

\begin{tabular}{cccccc}
\hline $\begin{array}{c}\text { Varyansın } \\
\text { Kaynağı }\end{array}$ & Tip III $\in \mathbf{X}^{\mathbf{2}}$ & df & $\overline{\boldsymbol{X}}^{\mathbf{2}}$ & $\mathbf{F}$ & $\boldsymbol{p}$ \\
\hline Ön-test genel & 2258.196 & 1 & 2258.196 & 10.690 & .003 \\
Grup & $\mathbf{6 5 . 6 8 4}$ & $\mathbf{1}$ & $\mathbf{7 9 . 0 4 9}$ & $\mathbf{. 3 1 1}$ & $\mathbf{. 5 8 1}$ \\
Hata & 6129.086 & 29 & 211.244 & & \\
Toplam & 57464.000 & 32 & & & \\
\hline
\end{tabular}

Deney1 ve Kontrol1 grupları arasında Türkçe geometri bilgi erişi düzeylerinin farklılığı için yapılan ANCOVA testi sonucunda gruplar arasında anlamlı bir fark olmadığı 


\section{Karakaya-Özyer}

ortaya çıkmıştır. Diğer bir ifadeyle Deneyl grubuna yapılan zenginleştirilmiş ortamla öğretim uygulamaları etkili olmamıştır.

Deney2 ve Kontrol2 gruplarının Türkçe geometri genel testi erişi düzeylerinin farklı olup olmadığını öğrenmek için daha önce yapıldığı gibi ön-test puanlarının ortalamalarının farklı olup olmadığı analiz edilmiştir. Bu analize yönelik sonuçlar aşağıdaki Tablo 8'de verilmiştir.

Tablo 8

Deney2 ve Kontrol2 Grubu Öğrencilerinin Türkçe Geometri Bilgi Ön-test Puanlarının Mann Whitney-U Testi Sonuçları

\begin{tabular}{cccccc}
\hline Grup & n & Fark & Sira Toplamı & Z & $\boldsymbol{p}$ \\
\hline Deney2 & 16 & 13.25 & 212.00 & -.940 & $.347^{*}$ \\
Kontrol2 & 12 & 16.17 & 194.00 & & \\
\hline
\end{tabular}

$* p>0.05$

Mann Whitney-U testi sonucu gösteriyor ki iki grubun da ön-testlerden aldıkları puanlar arasında anlamlı bir fark yoktur. Başka bir ifadeyle, Deney2 ve Kontrol2 grupları genel Türkçe geometri testi sonuçlarına göre eşlenmiş gruplardır. $\mathrm{Bu}$ durumda, iki grubun arasındaki farkı gözlemlemek için bağımsız örneklem t-testi uygulanmalıdır (Büyüköztürk, 2015). Tablo 9'da bağımsız örneklemler t-testi sonuçları verilmiştir. Bu tabloya göre yapılan bağımsız örneklem t-testi sonucu iki grup arasında anlamlı bir farklılık vardır $(p<.05)$. Ancak grupların Türkçe geometri bilgi erişi düzeylerinin ortalamalarına bakıldığında Kontrol2 grubunun genel bilgi açısından daha yüksek erişi düzeyine sahip olduğu sonucunu çıkartmaktadır.

Tablo 9

Deney2 ile Kontrol2 Grupları Arasında Türkçe Geometri Bilgi Erişi Düzeyleri Farklılı̆̆ Testi Sonuçları

\begin{tabular}{ccccccc}
\hline Grup & $\mathbf{n}$ & $\overline{\boldsymbol{X}}$ & $\mathbf{s s}$ & $\mathbf{d f}$ & $\mathbf{t}$ & $\boldsymbol{p}$ \\
\hline Deney2 & 16 & 9.00 & 5.94 & 26 & 3.27 & .003 \\
Kontrol2 & 12 & 16.67 & 6.28 & & & \\
\hline
\end{tabular}

\section{TARTIŞMA}


Araştırmanın probleminde kavramsal ve işlemsel bilgi düzeylerini birleştirerek yabancı öğrencilerin durumlarını incelemek amaçlanmıştır. Genel Türkçe geometri erişi düzeyinde de diğer bilgi düzeylerinden fark olmayarak tüm gruplar kendi içlerinde değerlendirildiğinde anlamlı gelişmeler göstermişlerdir. Ancak deney ve kontrol grupları karşılaştırmalarında anlamlı sonuçlar çıkmamıştır.

$\mathrm{Bu}$ bulgular bağlamında yabancı öğrencilerin matematik öğretimiyle ilgili yapılacak çalışmalarda öğrencilerin matematiğe karşı tutumları ve onların hangi alanda kariyer yapacakları gibi dışsal faktörleri göz önüne alarak bir araştırma modeli kurgulamak gerekmekte olduğu ortaya çıkmıştır.

\section{KAYNAKÇA}

Akdağ, M., \& Tok, H. (2008). Geleneksel öğretim ile powerpoint sunum destekli

öğretiminöğrenci erişisine etkisi. Ĕgitim ve Bilim, 33(147), 26-34.

Aktaş, T. (2005). Yabancı dil öğretiminde iletişimsel yeti. Journal of Language and

Linguistic Studies, 1(1).

Baki, A., Güven, B., \& Karataş, İ. (2004). Dinamik Geometri Yazılımı Cabri ile

Keşfederek Matematik Öğrenme. V. Ulusal Fen Bilimleri ve Matematik Ĕ̆itimi Kongresi Bildiri Kitabl, 2, 884-891.

Bartsch, R. A., \& Cobern, K. M. (2003). Effectiveness of PowerPoint presentations in lectures. Computers \& Education, 41(1), 77-86.

Büyüköztürk, Ş. (2015). Sosyal bilimler için veri analizi el kitabı: Ístatistik, araştırma deseni, SPSS uygulamalarl ve yorum. Ankara: Anı Yayıncılık.

Ceyhan, A., \& Türnüklü, E. B. (2002). Matematik öğretiminde kullanılabilecek bir materyal: çalışma yaprakları. Çă̆daş Eğitim Dergisi, 27(292), 37-46.

Demirel, Ö. (1993). Yabancı Dil Öğretimi, Illkeler, Yöntemler, Teknikler. Ankara: Usem Yayınları. 


\section{Karakaya-Özyer}

Demirel, Ö., Seferoğlu, S. S., \& Yağc1, E. (2002). Öğretim teknolojileri ve materyal geliştirme. Ankara: Pegem A Yayıncılık.

Dogan, M., \& Içel, R. (2011). The role of dynamic geometry software in the process of learning: GeoGebra example about triangles. International Journal of Human Sciences, 8(1), 1441-1458.

Edmondson, W., \& House, J. (1993). Einführung in die Sprachlehrforschung. Francke.

Erol, Ç., Özdemir, Ș., Özen, Z., Akadal, E., \& Ayvaz Reis, Z. (2012). Fibonacci spiral in sunflower with GeoGebra. Journal Of Education And Instructional Studies In The World, 2, 25.

Hand, B., \& Treagust, D. F. (1991). Student achievement and science curriculum development using a constructive framework. School Science and Mathematics, 91(4), $172-176$.

İçel, R. (2011). Bilgisayar destekli ögretimin matematik başarlsına etkisi: GeoGebra örneği (Doctoral dissertation, Selçuk Üniversitesi Eğitim Bilimleri Enstitüsü).

Özdemir, A. Ş., \& Tabuk, M. (2004). Matematik dersinde bilgisayar destekli öğretimin öğrenci başarı ve tutumlarına etkisi. Abant İzzet Baysal Üniversitesi Eğitim Fakültesi Dergisi.

Toptaş, V. (2008). An Examination of the Teaching-Learning Process and Teaching Materials Used in the Instruction of Geometry Sub-Learning Fields in a First Grade Classroom. Ankara Üniversitesi Eğitim Bilimleri Fakültesi Dergisi,41(1), 299-323.

Yiğit, N., Akdeniz, A. R., \& Kurt, Ş. (2001). Fizik öğretiminde çalışma yapraklarının geliștirilmesi. Yeni Bin Yllın Başında Türkiye'de Fen Bilimleri Eğitimi Sempozyumu, Maltepe Üniversitesi, İstanbul, 151-157. 